\title{
Strengthening Institutional Capacity for MDGs Acceleration through Media Activism in India
}

\author{
Rajesh Kumar \\ School of Social Sciences, Guru Nanak Dev University, India
}

Copyright $\bigcirc 2019$ by authors, all rights reserved. Authors agree that this article remains permanently open access under the terms of the Creative Commons Attribution License 4.0 International License

\begin{abstract}
When good governance is the condition for socio-economic development and success of MDGs in developing countries, media activism assumes a lot of significance in a country like India, which has a large population (41.6 percent) suffering on account of multi dimensional poverty index (UNDP Human Development Report 2011: 144). Print and electronic media both, through proliferation of multi-city editions of newspapers and 24 hours national and regional television news channels, have been making important influence on legislation and policy formulation in India. In recent past, India has witnessed a lot of media activism on variety of issues: Ombudsman (Lokpal); anti-corruption movement; sexual harassment of women; environmental degradation; female foeticide; caste related social deprivations; campaigns for food security; and right to information. Sustained media activism would go a long way in strengthening institutional capacity by increasing its coverage of people's participation, transparency, accountability and non-discrimination, especially in public expenditures and procurement in the name of pro-poor programmes for Millennium Development Goals (MDGs) acceleration. The paper looks at how MDGs in terms of their coverage content are reported by the media in India. It analyses media activism that resulted in essential interventions, setting up of a functional regulatory framework, mechanisms to address corruption, and efforts to assess performance. Finally paper explores whether media's activism can be sustained when states weakened by the requirements of policy frameworks of neo-liberalism and more corporate houses are assuming control over Indian media. Two case studies are discussed for substantiating the impact of media activism for strengthening of institutional capacities for MDGs acceleration in India. First: Telecast of weekly television programme of 'Satyamev Jayatey (Triumph of truth)'; and second: Media's coverage of people's movement against corruption and their demand for the setting up of 'Lokpal' (Ombudsman) for the trial of public servants involved in corruption charges. The role of New Media (Social Media) activism through internet sources for MDGs acceleration cannot be underestimated, but they remain beyond the purview of this paper.
\end{abstract}

Keywords Millennium Development Goals (MDGs), Media Activism, Democracy, Good Governance

\section{Introduction}

Media acting as watchdog in any democratic set-up is very essential for inclusive growth and its sustainability. Its coverage of developmental issues is very important for the protection of citizen's rights and ensuring accountability of the government in any democratic country. When good governance is the condition for socio-economic development and success of Millennium Development Goals (MDGs) in developing countries, media activism assumes lot of significance in a country like India which according to UNDP Human Development Report 2011 [1, p.144] has a large population (41.6 percent) suffering on account of multi dimensional poverty index. As on date, exponential proliferation in multi-city editions of newspapers and 24 hours national and regional television news channels have been making important influence on legislation and policy formulation in India. Despite allegations being made that Indian media is going more after glamour only and is reluctant in reporting on issues of bad governance, delays in achieving targets of MDGs and environmental degradation in the country, because of their economic interests and ownerships by corporate houses and risks of revenue losses on account of government advertisements. But, at the same time, Indian English national newspapers like The Hindu, The Indian Express and a handful of 24 hours television news channels private and public both: like, NDTV Hindi( local national language) cum English news channels; Star news television channel; public broadcasters like Doordarshan News (name of the largest Govt. of India owned news T.V. channel); Lok-Sabha (Govt. of India T.V. channel for coverage of proceedings of Lower House of Indian Parliament) and Rajya Sabha (Govt. of India T.V. channel for coverage of proceedings of Upper House of Indian Parliament), and only a few more national channels telecasted programmes on development and environment 
related issues on regular basis. A distinct divide exists in India between print media and electronic media so far the coverage of MDGs issues is concerned. Sustained media activism would go a long way in strengthening institutional capacity by increasing its coverage of people's participation, transparency, accountability and non-discrimination, especially in public expenditures and procurement in the name of pro-poor programmes. Media activism increases pressure on the government officials for improving delivery mechanisms, fixing of responsibilities, delays, cases of corruption leading to resignations, preventing of resource leakage, concerns for environmental degradation, and injustice related issues.

The paper looks at MDG era issues only (as Y2015 onwards, MDGs stand subsumed under Sustainable Development Goals), in terms of their coverage content are reported by the media (national and regional/local media, print and electronic). The paper presents an analytical framework for conceptualizing the relationship between media and the role of government in the context of expanded media activism for strengthening of institutional capacity for good governance and MDGs acceleration. It analyses media activism that resulted in essential interventions, setting up of a functional regulatory framework, mechanisms to address corruption, and efforts to assess performance. Finally paper explores whether media's activism can be sustained when states weakened by the requirements of policy frameworks of neo-liberalism and more corporate houses are assuming control over media.

The methodology used for completing paper includes content analysis of press coverage reviews and impact of television programmes (national and local) during 2010-13 period. The weekly T.V. programmes aired have been accessed through web sources. Two case studies are discussed for substantiating the impact of media activism for strengthening of institutional capacities for MDGs acceleration in India. First: Telecast of 'Satyamev Jayate' (Triumph of truth)' weekly programme; and Second: Media's coverage of people's movement led by Anna Hazare for setting up of Lokpal (Ombudsman) at the centre as well as in all the Indian states for trial of corruption charges involving public servants. The role of New Media (Social Media) activism through internet sources for MDGs acceleration cannot be underestimated, but they remain beyond the purview of this paper.

\section{Theoretical Contextualisation}

Reforms are urgently needed to improve the responsiveness, transparency, effectiveness, and accountability of governance institutions so that public services work for the poor as well as the rich. Quoting the World Bank Report, Moyer says, within the broad context of the major issues facing the international development community, a diverse and independent media sector can be an effective way to increase government accountability and to benefit the poor by enhancing their participation and dialogue [2]. He adds that the media also serve as a conduit between governors and the governed and as an arena for public debate that leads to more intelligent policy- and decision-making [2]. Even Amartya Sen outlines the need for "transparency guarantees" such as a free press and the free flow of information. These guarantees, he wrote, "have a clear instrumental role in preventing corruption, financial irresponsibility and underhanded dealings" [3]. Amartya Sen also sees the media as a watchdog not just against corruption but also against disaster... The normative view of the press argues that the conduct of the media has to take into account public interests [3]. The social responsibilities expected from media in the public sphere were deeply grounded with the acceptance of media as the fourth estate, a term coined by Edmund Burke in England [4, p. 2]. Locksley says, new media do not displace old, rather, they sit side by side [5, p.2]. As said, in many developing countries of the World, the media has very important role to play like: strengthening democracy; social development; gender equality; nation building; education provision; and finally, safeguarding the spiritual and moral fiber of society. Safeguarding, enriching, and strengthening the countries cultural, political, social, and economic fabric is also done by media. It is this role of Indian media is under study, which is essential for MDGs acceleration in developing countries like India.

\section{Millennium Development Goals (MDGs) Acceleration Strategies for Developing Countries}

\subsection{The MDG Action Agenda 2010-2015}

At the outset, a point need to be mentioned here that since 2015, MDGs stand subsumed under Sustainable Development Goals (SDGs) under the United Nations [6]. However, the discussion in this paper pertains to MDG era only. As per the UNDP Report 2012, the discussions regarding MDG achievements, gaps and emerging constraints point to five broad conditions for success. First, country-led development and effective governance are necessary. Second, private sector led and inclusive economic growth, with a focus on agricultural productivity, can help meet the targets for poverty reduction and hunger. Third, scaling up public investments in physical infrastructure and human capital is necessary for both crowding in the private sector and expanding basic services, including health and education. Fourth, quick gains can be made through carefully targeted interventions, including innovative social assistance schemes and public employment programmes. Fifth, climate change adaptation and low carbon development provide opportunities for sustainable MDG acceleration. Effective partnerships with non-governmental organizations, the private sector and civil society can help bring these strategies to fruition [7, p.20]. The MDGs 
continue to provide the road map for reducing poverty and hunger, saving children and mothers from premature death, providing sustainable and decent livelihoods, and preserving the environment for future generations. At the same time, MDG progress is threatened by the combination of high food prices and the impact of the international financial and economic crisis... Weak institutional capacity in conflict and post conflict environments slows MDG progress. Rapid urbanization and growth in slum dwellings are putting pressure on social services [7, p.21].

The UNDP 2012 Report also highlights several other concerns. The United Nations MDGs assessment notes that there are important synergies among the MDGs acceleration in one goal often speeds up progress in others. In households where women are illiterate, child mortality is higher, implying the links between education, the empowerment of women and the health of children hence this requires multi-sectoral approaches and coordination among various implementing agencies [7, p.22]. Equitable provision of land and agricultural inputs significantly increases output and ensures food security. Constitutional and legal reforms enhance women's empowerment and increase their political participation... Targeted interventions, including social protection and employment programmes are key to MDG acceleration. Mass immunization and the distribution of bed nets and antiretroviral drugs contribute to saving lives. Supporting the diversification of livelihoods away from climate-sensitive activities is an essential MDG strategy. Domestic resource mobilization is the primary source of sustainable MDG financing. [7, p.23-25].

\subsection{Global Partnerships and Resource Mobilization}

The Report further says, progress has been made, but it is uneven. The number of people who are undernourished has continued to grow; about one in four children under the age of five are underweight, mainly due to lack of food and quality food, inadequate water, sanitation and health services, and poor care and feeding practices. An estimated 1.4 billion people were still living in extreme poverty in 2005. Gender equality and the empowerment of women are at the heart of the MDGs and are preconditions for overcoming poverty, hunger and disease. But, progress has been sluggish on all fronts-from education to access to political decision-making [8, p.3]. Aid shortfalls and external debt is considered as the main constraints, whereas global financial volatility, while recognized as a problem, was not explicitly linked to development goals. Quoting IMF and World Bank estimates, Bond says, achieving the MDG targets would cost $\$ 54$ billion per year, [9, p.339]. On the other hand, reality is that around \$ 6.2 trillion dollars worth black money have been stashed abroad by the elites of the world, mostly from developing world. As per Transparency International, $\$ 500$ billion dollars belonging to Indians have been stashed abroad raising a very serious issue of punishing the defaulters [10].

\section{Media Activism and Stregthening of Institutional Capacities}

\subsection{Media and Indian Democracy}

Corneo says, the media in India has a role to play behind formation of public opinion which can force the political parties to address the core issues haunting the country's progress [11]. Another media expert, Coronel says the news media need the active support of groups in civil society in order to strengthen the commitment of each political community to free, diverse, and independent media. The news media play a crucial role in creating that sense of community [12]. As discussed, there is an important link between media and civil society; rise in the increased role of civil society marks a shift from government to governance with governance involving a far larger group of participants and players. According to the World Bank Report of June1994: Good governance is epitomized by predictable, open, and enlightened policy making, a bureaucracy imbued with a professional ethos acting in furtherance of the public good, the rule of law, transparent processes, and a strong civil society participating in public affairs [13].

\subsection{Public Broadcaster-Govt. of India Owned (Doordarshan (D.D. Television) News Channel's Role in India and MDGs Accelerations}

In India, All India Radio (AIR) and Govt. of India -Doordarshan (D.D. Television) \{AIR and DD are names of the largest Govt. of India owned radio and T.V. news channels $\}$ are the public service broadcasters who have the responsibility of providing educational programs apart from information and entertainment and both also act as agents of social change. As per the author's own survey [14] of television programmes being telecast daily in India during the period under study, the Public Broadcaster in India i.e., Government of India owned, - Doordarshan (Television) News Channel remained ahead of all private television news channels in sheer numbers of programmes telecasted covering MDG issues through programmes like; Mehnat Rang Layagi (Labour Yields Dividend), Ehsas (Feelings), Badi Charcha (Big Discussion), Total Health, Janane Ka Haq Hai (Right to Information), Mere Desh Ki Dharti (My Country's Land), Gaon Har Hafte (Village Every Week), Reporter's Diary and Focus. Public Broadcaster, Govt. of India owned, Prasar Bharti Corporation- Doordarshan's (Television) other sister concern channels like Lok Sabha Channel (Govt. of India owned T.V. channel for coverage of proceedings of Lower House of the Indian Parliament) telecasted programmes most often that covered MDGs issues through programmes like; Insight Weekend, Legal Point, India Unlimited, Public Forum, Healthy India, Public Domain, Anchal Mein Akash (Sky in Laps) , Gender Discourse, Sansad Se Sadak Tak (From Parliament to Road) and Hamari Sansad (Our Parliament). At the same time, 
Rajya Sabha Channel ((Govt. of India owned T.V. channel for coverage of proceedings of Upper House of the Indian Parliament) aired programmes focusing upon MDG issues under news and current affairs programmes itself. In total, it can be said that in term of total hours of programme as well as total number of programmes covering MDGs, the Public Broadcaster Govt. of India owned -Doordarshan (D.D. Television) and its sister concern remained much ahead of the most of private T.V. news channels.

\subsection{Private National T.V. News Programme Broadcaster's Role in India and MDGs Accelerations}

The private sector media's potential influence is also felt in a number of areas like reporting violation of children and females human rights that educated people and shaped up public opinions in India. Indeed, human rights specially, of children, females and their empowerment, issues like corruption free India, were salient issues with the private print as well as electronic media, making it politically attractive for members of Indian Parliament to pursue legislation on related matters in last few years. It can be said that without media support, lobbying by a civil society organisation 'India Against Corruption', NGOs like AIDWA (Women NGO), PRATHAM (Education NGO) and many others would not have succeeded in getting important legislations having ramifications for MDGs accelerations passed. All such findings showed a lot of variation among public owned and privately owned 24 hours television news channel groups. Public broadcaster- Doordarshan (D.D. Television) and its sister channels remained far ahead of all other television channels and always shared bigger responsibility towards the citizens of the country in informing them about MDGs and their achievements. So far private broadcasters were concerned; the name of NDTV remained at the top.

As per the author's personal survey [14], news reports in newspapers like The Hindu titled 'Periscope', 'Development and Rights' served as an informal means of documenting human rights violations especially of poor, children and females. The Hindu, national English daily newspaper, carried news item covering different aspects of MDGs all the seven days of a week. On the contrary, many other national English dailies, made only passing references to press conferences held by United Nations Officials at the time of releasing MDG Reports pertaining India or news regarding 'World Summit on Sanitation' being held in New Delhi, India did appear in national dailies. All such findings showed a lot of variation among privately published news papers groups.

The Indian electronic media in recent years increasingly supported the NGOs and civil society organizations by emphasising upon women empowerment and corruption free India related issues being set on the national agenda. Rights of children and females, demand for Lokpal Bill (Ombudsman) always received attention of electronic media more frequently. Weekly T.V. programmes like 'Satyamev Jayate' (Triumph of truth) telecasted by Star News (ABP) channel ensured that issues of corruption, female foeticide, inter-caste marriages and other Dalits (marginalised sections of the society) related issues in India are highlighted through their periodic shows but the show got discontinued after twelve episodes only. Even Star T.V. did not telecast programme on daily basis. As per author's survey, the NDTV India (Hindi) aired Weekly Programmes like Documentary, 'Muqabala' and 'Humlog' on weekends covering issues of women, children and poverty. NDTV 24x7 (English Channel) telecasted programmes on weekends like 'Big Fight', 'Britannia Nutrition Foundation' and 'We the People' highlighting MDGs' issues. It also led a campaign for generating awareness about environmental issues by telecasting programmes like 'Greenathon' nearing Environment Day celebration in the country. Most of the other channels remained inspired by commercial gains and telecasting of MDG programmes would not have given them the desired TRPs. Other channels only carried information in their news programmes or as part of discussions only. Except NDTV group, no other national private T.V. news channels which included reputed one like 'Zee T.V. or Aaj Tak' (T.V. Today) ever telecasted any MDG related programme on daily basis. [14]

\section{Two Case Studies}

It is important to discuss two case studies for substantiating the impact of media activism for strengthening of institutional capacities through enactment of new legislations for MDGs acceleration in India. First: Telecast of 'Satyamev Jayate'(Triumph of truth) weekly programme though it was telecast for only 12 weeks; and Second: Media's coverage of people's movement against corruption led by social activist Anna Hazare for setting up Lokpal (Ombudsman) at the centre as well as in the Indian states for trial of public servants and government officials facing corruption charges. Undoubtedly, media coverage of setting up of Lokpal (Ombudsman) Office's movement in India had been historical. The electronic media coverage so far was the biggest one which shook the Federal government and compelled it to introduce the Lokpal (Ombudsman) legislation bill inside the Federal Parliament. At the same time the telecast of 'Satyamev Jayate' programme by Star T.V. drew massive response from audiences all over the country and created history in the country as it also led to enactment of several legislations in the country having bearing for MDGs acceleration in the country.

\subsection{Weekly T.V. Programme 'Sataymev Jayates' (Triumph of Truth's) Impact}

Weeks after telecast of famous actor Amir Khan produced and anchored TV series Satyamev Jayate (Triumph of truth), a television programme which showed socio-economic 
realities of the country. In one of the episodes, anchor talked about problems being faced by physically challenged children in getting admission in schools. The telecast of the programme led to Delhi government's decision to carry out a survey of such kids in the city to extend them educational facilities [15]. Since then, Indian judiciary also has taken tough stand against all schools in Delhi and other parts of the country for admitting disabled children. Emerging story. Watch this space for updates as more details come in

Taking cue from Aamir Khan's serial Satyamev Jayate (Triumph of truth), Bihar's health minister Ashwini Kumar Choubey Choubey undertook a 30-km march for launching the Bitiya Bachao Andolan (Save the Girl Child Movement) in the state, a mass awareness drive against the rising incidents of female foeticide cases [16]. Krishna Tirath, Union MOS for Women and Child Development, described Aamir Khan's debut TV show Satyamev Jayate (Triumph of truth) as a successful effort and lauded his campaign against the rampant practice of female foeticide in the country. Tirath believed that such social evils can be stopped through mass awareness campaigns and greater public participation only in India [17]. (Daily Bhaskar, May 10, 2012). Empowerment of women was the only long-term solution. Otherwise, the wide-spread killing of unborn girls will continue, said Aradhana Patnaik, state project director of National Rural Health Mission (NRHM) [18].

Spurred by actor Aamir Khan's demand for making generic drugs available to patients for reducing their medical treatment related financial burden, the Union Health Ministry on Friday said such medicines will be available at all Government hospitals from October-November 2012. It meant, 348 essential drugs under the National List of Essential Medicines (NLEM) will be available free-of-cost to out-patients as well as in-patients in Government hospitals and the officials hope to kick off the scheme later this year [19]. "We have estimated '28,560 crore for 12th Five-year Plan of which ' 100 crore will be needed this year to start distribution of generic medicines in the provincial States," said LC Goyal, Additional Secretary, Health Ministry [19]. Aamir Khan, the actor and producer in one the episode's of his weekly show 'Satyamev Jayate' (Triumph of truth) on May 27, 2012 and subsequently in his column in some newspapers had suggested the use of generic drugs as a key to affordable healthcare for India's poor. Subsequently, on the invitation of a Parliamentary panel on Health, Khan yet again espoused the cause (Ibid.,). Even the Karnataka government decided to start selling generic drugs at subsidized rates, almost $50 \%$ less than the MRP (www.health.india.com). Amir Khan, host of the show 'Satyamev Jayate' (Triumph of truth) won another battle when the Lok Sabha (Lower House) also passed the Child Protection Bill and Women Sexual Harassment Bill 2012 which was pending for long after the telecast of one of the episodes on child abuse [20]. The massive support people of India gave to this programme that on social media it created a record (Social Media Snapshot of Satyamev Jayate (Triumph of truth)) [21].

\begin{tabular}{|c|c|c|}
\hline \multirow{3}{*}{ Facebook Buzz } & $\bullet$ & Likes: 660,643 \\
\hline & $\bullet$ & People talking about: 382,319 \\
\hline & $\bullet$ & Facebook public posts: 1712 \\
\hline \multirow{2}{*}{ Twitter Buzz } & $\bullet$ & Followers: 15135 \\
\hline & $\bullet$ & Following: 60 \\
\hline \multirow{5}{*}{ YouTube Buzz } & $\bullet$ & Total tweets and retweets: 35306 \\
\hline & $\bullet$ & Among top 5 in Twetter Trends India \\
\hline & $\bullet$ & Total views: 353,255 \\
\hline & $\bullet$ & Ratings: 5221, Likes: 5142, Dislikes: 79 \\
\hline & $\bullet$ & Comments: 1,374 Favorites: 538 \\
\hline \multirow{4}{*}{ Google Trends } & $\bullet$ & "Satyamev Jayate" became the most searched \\
\hline & $\bullet$ & word in India on 6th May \\
\hline & $\bullet$ & Google Trend analysis shows a steep spike \\
\hline & $\bullet$ & during the $11 \mathrm{am}-12 \mathrm{pm}$ broadcast on 6 th May \\
\hline
\end{tabular}

The media can act as a force against corruption in ways that are both tangible and intangible. Its activism might force launching of investigation by authorities, the scrapping of a law or policy that fosters a climate ripe with opportunities for corruption, the forced resignation of a politician, the firing of an official, the launching of judicial proceedings, the issuing of public recommendations by a watchdog body, and so on. Intangible effects, by contrast, can be characterized as those checks on corruption which arise from the broader social climate of enhanced political pluralism, enlivened public debate and a heightened sense of accountability among politicians, public bodies and institutions that are inevitably the by-product of a hard-hitting, independent news media. [22]. Similar roles got performed by Indian media when it broke news regarding mega scams like Common Wealth Game Scam involving INR 70,000 crore, 2-G spectrum scam involving a sum of INR1,76,000 crore and most recently the coal scam involving a sum of INR $1,86,000$ crore (1 crore is 10 million) [22].

\subsection{The Lokpal (Ombudsman) Movement}

The movement against corruption may have come to life at the end of year 2011 after a string of high-profile corruption scandals. With the nexus of the state with corporations, the poor losing more and more of their assets and the governing class increasing their wealth and publicly vulgarizing it, there was a pent-up anger in India against the political class, especially, the ruling classes. It was this anger that came to the streets during agitation for passing of Lokpal Bill (Ombudsman legislation) by the federal parliament. The media's role had been immense in generating awareness on part of common citizens through most of the news items related with corruption (reflecting cases of crony capitalism) highlighting involvement of India's governing class besides other scandals like $2 \mathrm{G}$ scam, land scandals and loot and plunder of public wealth. As per a study [23] 
About $15 \%$ of the 542 Lok Sabha and 245 Rajya Sabha MPs face serious criminal charges for murder, rape and extortion. A High Court judge of West Bengal faced impeachment by Parliament and the Chief Justice of Sikkim took voluntary retirement. There have been serious charges of corruption against some judges of the Supreme Court... The Lokpal debate is merely a trigger for the sense of inchoate rage they feel against a political system which displays contempt for their priorities...., EDITED ON: Jun 21, 2012 22:02 IST

The media activism led to introduction of 'Lokpal Bill' (Ombudsman legislation) in the Federal Parliament which was duly passed by the Lower House of the Federal Parliament however it could not be passed by the Upper House of the Federal Parliament. This aspect is discussed in detail in subsequent section.

\section{Legislative Outcomes through Media Activism for Strengthenining Institutional Capacities for Mdgs Acceleration}

\subsection{Women Reservation Bill}

An historic development pertaining to women's empowerment in India happened in India in 1993. Through, the $73^{\text {rd }}$ and $74^{\text {th }}$ Constitutional Amendment in existing Indian Constitution, one third of total legislative seats for women in village and urban bodies (Local Government level) was reserved exclusively for women of India [24]. Upbeat about the success of women at local government bodies level, Federal Indian Government introduced $110^{\text {th }}$ and $112^{\text {th }}$ Constitutional Amendment bill in the parliament in 2012 for increasing the limit of reservations for women from $1 / 3$ to $1 / 2$ (one third to an half of total number of seats) in local government bodies [24]. The Federal Indian Government had already got $10{ }^{\text {th }}$ Constitutional Amendment bill passed by the Rajya Sabha ( The Upper House of Federal Parliament) seeking $1 / 3$ Reservation of seats for women in Union and all 29 State Legislatures of India.[24] All such steps have proved to be historic milestones for achieving the MDG goals of women empowerment. Passing of Protection of Women from Domestic Violence Act, 2005 by the Federal Indian Parliament has made a huge difference in women empowerment's direction. Making public spaces safe for women would be a major step forward in enhancing women's access to these spaces [24]. Das says that education and other, more subtle barriers continue to blunt the aspirations of women in this and other areas. [25; p.164-66] The passing of Prohibition of Sexual Harassment at Place of Work Bill, 2012, further empowered Indian women all over the country. [24].

\subsection{The Lokpal Bill (Ombudsman Legislation Bill), 2011}

The Lokpal Bill was introduced in the Lower House of Federal Parliament on 4th August, 2011. The Bill (Annexure-A) seeks to provide for the establishment of the institution of Lokpal to inquire into allegations of corruption against certain public functionaries and for matters connected therewith or incidental thereon. The Statement of Objects and Reasons appended to the Bill (www.rajyasabha.nic.in) reads as under and seeks to [26]:

(i) to establish an Institution of Lokpal with a Chairperson and eight Members of which fifty per cent shall be Judicial Members; (ii) to set up Lokpal's own Investigation Wing and Prosecution Wing with such officers and employees a felt by it to be necessary;....(iv) To provide for a mechanism to ensure that no sanction or approval under section 197 of the Cr.p.c. 1973 or section 19 of the Prevention of Corruption Act, 1988, will be required in cases here prosecution is proposed by the Lokpal...

However, the Bill could not be passed by the Upper House of Federal Parliament as all political parties of the country expressed undue concerns and worries about bill's harsh contents, hence, all political parties got united and prevented the bill from getting passed rather they got it transferred to select Committee of the Federal Parliament for depth study, a delaying tactics.

\subsection{Food Security Bill}

On December 22, 2011, the Union MOS for Consumer Affairs, Food and Public Distribution introduced the National Food Security Bill in the Lower House of the Federal Parliament. It was again the pressure exerted by different television programmes that showed ever rising cases of malnutrition, starvation deaths, spoiling of food grains in warehouses/godowns in many part of India because of inadequate/open storage space, resulting often into increased prices of food grains that finally led to the intervention of Supreme Court of India over matters of hunger death and free distribution of food grains among poor. Even the United Nations Report on MDGs highlighted concerns regarding higher prices and scarcity of food grains world over affecting the MDGs in following words [27]

As food prices increase, the purchasing power of the poor decreases, the composition of their diet worsens, and their food consumption may decrease. These changes directly affect all targets of MDG 1 on poverty, full and productive employment, and hunger. Malnutrition affects early childhood development and makes children more likely to drop out of school (MDG 2). An increase in food prices affects women and girls' consumption disproportionately (MDG 3)... Higher food prices have weakened intergovernmental coordination in food markets (MDG 8).

The Bill which aims "to provide for food and nutritional security in human life cycle approach, by ensuring access to adequate quantity of quality food at affordable prices to 
people to live a life with dignity" marks a "shift from the current welfare approach to right based approach to address the problem of food security". It endeavors to empower women and other marginalized sections of the society [28]. The National Food Security Bill, 2011 gives legal right to people living below the poverty line in the country being provided $25 \mathrm{~kg}$ of food grains at a subsidized rate of Rs. 3 per $\mathrm{kg}$ for rice, Rs. 2 per $\mathrm{kg}$ for wheat and Rs. 1 for millet. The Bill in its present form prioritized minimum 75\% rural and $46 \%$ urban population [28]

\subsection{Action Taken by Federal Government of India against Corruption and Black Money}

After having faced peoples' anger all over the country during the Anna Hazare and Ramdev's NGO led Ombudsman movement that was covered on round the clock basis by electronic media forced the Federal Government of India under opposition political parties pressure to take appropriate measures against corruption. The federal government then constituted a Committee to consult all stakeholders and submit their report on issue of Black Money within a period of six months. The Committee will examine the measures to strengthen the existing legal and administrative framework to deal with the menace of generation of black money through illegal means. As on date i.e., in 2017, India has already begun implementation of Prevention of Money Laundering Act (PMLA). The present Indian Government led by Prime Minister initiated several other steps for eradication of corruption in India like 'De-monetisation Step' in November 2016 and implementation of Goods and Services Tax (GST) from 01 July 2017 [29].

\subsection{Public Services Delivery Act}

Various other initiatives have already been taken by Federal Government, including Citizens' Charters, 'Sevottam' and the recently introduced performance management \& evaluation system. The Federal Government also introduced another Public Services Delivery Bill in Federal Parliament at the earliest and got prepared a Model Bill for adoption by State Governments. The Federal Government encouraged all State Governments to adopt the Model Bill to improve the quality and timeliness of public service delivery. All such steps resulted into enactment and implementation of Right to Service Act in many parts of the India [30].

\subsection{Social Safety Nets for Poverty Elimination}

The safety nets are programmes which seek to eliminate socio-economic deprivations. For example, programmes like the public distribution system (PDS) (food security), Employment Guarantee (minimal income security), SHG for saving and thrift (social mobilisation) help the hardcore poor to get out of the debt bondage, primary health centres (PHCs) and nutrition programmes reduce morbidity and resulting loss of efficiency and productivity, free and aided primary education and mid-day-meal scheme keep children in school giving them an opportunity to grow out of poverty [30; p.3397-3403]. All these measures were very important for MDGs' success in India by 2015.

\subsection{Triba's Forest Rights Act 2009}

There has been a systemic failure in giving the tribal people (indigenous) a stake in the modern economic processes of India which has a considerable tribal population ( 7.5 percent approximately of 1.25 billion) that inexorably intrude into their living spaces. The alienation built over decades is now taking a dangerous turn in some parts of our country said, Prime Minister Manmohan Singh [31] during Chief Ministers' Conference on Implementation of the Forest Rights Act, November 4, 2009. The response of the Federal Indian government to the vulnerability among tribal people has been proactive and has included a mix of constitutional measures, legislative enactments, programs supported by earmarked funds, and quotas in public employment and publicly funded education, the major problem has been implementation, says the World Bank Report. The most extreme form of attempting to wrest power is the widespread Maoist movement that claims to articulate the demands of Adivasis militantly [32].

\subsection{The Mahatma Gandhi National Rural Employment Guarantee Act (MGNREGA) 2005}

The MGNREGA, Act passed by the United Progressive Alliance (UPA-I) government led by Prime Minister Manmohan Singh in 2005 offers a minimum 100 days of employment per rural household living below poverty line. There are problems with such limitation, both in terms of the administrative costs associated with determining only 100 days and more significantly in terms of defining the household. It has been argued that limiting it to households will adversely affect women's employment and also that the poor tend to be concentrated in large households because of lack of resources, so that more people among the poor could be excluded from the programme. The guarantee is provided in all 630 districts of the country. The massive success of this act brought UPA government once again into power in 2009 . Enthused by the success of this programme government is likely to introduce similar guaranteed employment programme for poor living in urban areas also, which would be a very important step in the direction of MDGs [33].

\section{Conclusions}

As analyzed in the preceding sections, it can be concluded that media activism has resulted in key legislations being enacted in India in the $21^{\text {st }}$ century having direct bearing for MDGs success by 2015 in the country. Despite media's 
active role, highest number of malnutrition related children deaths approximately one million took place last year in 2016 in India alone. Though free and compulsory education for children between the age group of 6-14 under Right to Free and Compulsory Education (RTE Act) is being implemented still more than 20 million children are out of schools in India. Scandals in health sector under National Rural Health Mission (NRHM), a Flagship Programme of Federal Government in direction of Universal Right to Good Health are going to make it difficult for achieving the universal right to health for all very difficult. Conditions of women, especially from marginalized sections of the society continue to be worse on all socio-economic accounts. Around sixty percent population lacking access to basic sanitation facilities remains a matter of serious concern which is also an important reason for large number of deaths in India. Cases of corruption and poor delivery mechanisms have the potential to derail the MDGs now SDGs implementation in India.

\section{REFERENCES}

[1] United Nations Development Programme. What Will It Take to Achieve the Millennium Development Goals? - An International Assessment, U.S.A.: The U.N., (June 2010). p. 20. Available from www.un.org.com.

[2] Moyers, Bill. Overcoming Civic Literacy, (1999). In: Coronel, S. The Role of the Media in Deepening Democracy, (2003). Available from http://unpan1.un.org/intradoc/groups/public/d ocuments/un/unpan010194.pdf.

[3] Sen, Amartya. Development and Freedom. (1999). In: Coronel, S. (2003). The Role of the Media in Deepening Democracy. Retrieved from http://unpan1.un.org/intradoc/groups/public/d ocuments/un/unpan010194.pdf.

[4] Mc Quail, D. Mass Communication Theory. New Delhi: Vistaar Publications, (2005).

[5] Locksley, Gareth. The Media and Development: What's the Story? Washington D.C.: The World Bank Report, (2009). p. 2-3, accessed from www.worldbank.org/elibrary.

[6] United Nations. The Sustainable Development Goals. New York: The U.N.; (2010). Available from www.un.org

[7] United Nations Development Programme. What Will It Take to Achieve the Millennium Development Goals? - An International Assessment, U.S.A.: The U.N., (June 2012). p. 20-25. Accessed from www.un.org.com.

[8] United Nations. The Millennium Development Goals Report. New York: The U.N.; (2010). p. 3-5.

[9] United Nations. 'Report of the International Conference on Financing for Development', A/ CONF.198/11, Monterrey, Mexico, Statement by Mike Moore, Director-General, World Trade Organization, 22 March, 2002.In: Patrick Bond. Global Governance Campaigning and MDGs: From Top-down to Bottom-up Anti-Poverty Work, Third World Quarterly,(2006); 27(2). p. 339-354. Available from: Taylor \& Francis,
Ltd.Stable URL:http://www.jstor.org/stable/4017678 .Access ed: $28 / 05 / 2012$ 02:51

[10] Transparency International Report, (2014). Available from: www.transparency.org.com

[11] Corneo, G. Media Capture in a Democracy: The Role of Wealth Concentration. CES Working Paper, (2005).

[12] Coronel, S. The Role of the Media in Deepening Democracy, (2003), Available from http://unpan1.un.org/intradoc/groups/ public/documents/un/unpan010194.pdf.

[13] World Bank. Governance: The World Bank. Experience, New York: The World Bank; (1994).

[14] Author's Personal Survey of Television Programmes Telecasted during the period of study.

[15] Press Trust of India. (June 21, 2012).

[16] The Telegraph. (Wed, May 31, 2012).

[17] Satyamev Jayate impact: Women \& Child Development Minister promises action. (May 10, 2012). Available from: Dailybhaskar.com, 12:45PM IST

[18] The Telegraph. (Thursday, May 30, 2012). Also see www.nrhm.gov.in.

[19] Jyoti, Archana. Generic Drugs to be Available by Oct-Nov: Minister after Amir Pitch. New Delhi; The Pioneer, (June 2012).

[20] Vyavahare, Renuka. Lok Sabha passes child protection bill courtesy Aamir, The Times of India, (May 23, 2012). TNN, 11.34AM IST.

[21] Social Media Snapshot Of Satyamev Jayate. (May4-8, 2012). Buzz Trend, Accessed from www.simplify360.com

[22] Stapenhurst, Rick. (2000). The Media's Role in Curbing Corruption, World Bank Institute, pp.3-4. Accessed from, www.worldbank.org/library.

[23] Social Action (Oct-Dec 2011) Vol. 61, No. 34.

[24] For details of MNREGA Parliamentary Legislations/Acts visit :www.prs.in.org

[25] Das, M. B. What Money Can't Buy: Getting Implementation Right for MDG3 in South Asia. In: M. Buvinic', A. R. Morrison, A. W. Ofosu-Amaah, and M. Sjöblom. (eds.) Equality for Women: Where Do We Stand on Millennium Development Goal 3? Washington D.C.: The World Bank; (2008).p. 261-92. In: World Bank Report on Poverty and Social Exclusion. Available from: www.worldbank.org.

[26] Department Related Parliamentary Standing Committee on Personnel Public Grievances, Law and Justice Forty Eighth Report on the Lokpal Bill. New Delhi: Govt. Of India; (2011). Parliament of India Rajya Sabha. Available from www.rajyasabha.nic.in. Also for Ombudsman (Lokpal) Act details visit: www.prs.in.org

[27] Global Monitoring Report. Food Prices, Nutrition, and the Millennium Development Goals, (2012). Available from http://pmindia.nic.in/speech/content4print.asp?id=842.

[28] The National Food Security Bill. (2011). Right to Entitlement to Food and Nutrition Report- 2012. Accessed from, www.cuts-international.org. The National Consultation on the 
National Food Security Bill, 2011, Constitution Club, New Delhi. For details of the Food Security Act visit: www.prs.in.org

[29] For details of the Goods and Services Act visit: www.prs.in.org

[30] Rao, V. M. Making Safety Nets Effective for Hardcore Poor. Economic and Political Weekly, 2007 Aug 18-24; 42(33). p. 3397-3403. Available from: URL: http://www.jstor.org/stable /4419921 .Accessed: 28/05/2012 03:12

[31] www.pm.gov.nic.in

[32] World Bank Report. Poverty and Social Exclusion In India, 011. Washington D.C. The World Bank; (May 23, 2012). Available from www.worldbank.org, p.73-75.

[33] For details of the MGNAREGA Act visit: www.prs.in.org 